\title{
Effect of heart rate and respiratory rate on thermal infrared-imaging of the horse's head
}

\author{
Carsten Siewert', Maren Hellige², Nina Heuchert ${ }^{1,2}$, Karl Rohn ${ }^{3}$, Peter Stadler² and Hermann Seifert ${ }^{7}$ \\ Institute for General Radiology and Medical Physics, University of Veterinary Medicine Hannover, Germany \\ 2 Clinic for Horses, University of Veterinary Medicine, Hannover, Germany \\ 3 Institute for Biometry, Epidemiology and Information Processing, University of Veterinary Medicine Hannover, Germany
}

\begin{abstract}
Summary: The aim of this study was to investigate the influence of heart rate, respiratory rate - which are used among other parameters for evaluating pain - and body core temperature on infrared-imaging of the horse's head. The results should be a base for future studies for dectecting signs of pain in lateral IR-images of the head. Furthermore, an evaluation method was proposed which does not strongly depend on the effects of the named circulatory parameters on infrared (IR)-imaging. For this, lamefree horses without any clinical signs $(n=9)$ were exercised in a controlled manner on a treadmill. Prior to exercising (measuring time point: MTP1) and after a 10 min walk (MTP2), 5 min slow trot (MTP3) and 5 min fast trot (MTP4) thermographic images of the lateral views of the horse's head were taken and the named physiological parameters recorded as well. The taken IR-images were evaluated, taking into account the anatomical structures of the horse's head so as to define the Regions of Interest (ROIs). Assessment of the change in surface temperature was carried out by calculating unilateral temperature differences $(\Delta \vartheta)$ between the maximum temperature $\left(\vartheta_{\text {max }}\right)$ in the region of the medial angle of the eye (ROI1) or the region of the eye (ROI2) and the average temperatures $\left(\vartheta_{m}\right)$ of the remaining ROls (ROII, ROI3-6). The ROls were defined above blood vessels. It was apparent in the course of exercise after MTP3 that some calculated temperature differences were significantly reduced ( $\Delta$ YROI6 and $\Delta \vartheta R O I 5.3)$. ROI6, the region arteria angularis occuli, showed an instable course $(\Delta \vartheta R O 16)$ with a large relative percent range of variation of $36 \%$. This measuring area is located after the arteria dorsalis nasi has left the end artery of the arteria facialis. In contrast to this ROI4 positioned at the ventral edge of the horse's head rostrally from the muscle masseter $(\Delta \vartheta R O \mid 4)$ showed the most stable course, a small relative percent range of variation with $8 \%$ and insignificant $(0.8 \geq p \geq 0.2)$ Wilcoxon signed rank (multiple comparison test) over the whole time span among all defined temperature differences during the entire examination period. Further studies for dectecting signs of pain in IR-images of the head seem to be reasonable.
\end{abstract}

Keywords: infrared-imaging / horse / head / circulatory parameters / thermal imaging / treadmill / diagnostic imaging

\section{Einfluss von Herz- und Atemfrequenz auf die Infrarot-Bildgebung am Pferdekopf}

Ziel dieser Studie war es, den Einfluss von Herzfrequenz, Atemfrequenz und Körperkerntemperatur auf das thermische Infrarot(IR)-Bild des Pferdekopfes zu untersuchen. Die Ergebnisse sollten möglichsł als Basis für zukünftige Untersuchungen zur Erkennung von Anzeichen für Schmerzen im lateralen IR-Bild des Kopfes dienen. Des Weiteren wurde eine Auswertmethode vorgeschlagen, die vom Einfluss der genannten Parameter auf die Infrarot-Bildgebung möglichst unabhängig ist. Dafür wurden klinisch unauffällige, lahmfreie Pferde ( $\mathrm{n}=9)$ einer kontrollierten Belastung auf dem Laufband ausgesetzt. Vor Beginn der Belastung (Messzeitpunkt: MZP1) und jeweils nach 10 min Schritt (MZP 2), 5 min langsamen Trab (MZP3) und 5 min schnellem Trab (MZP4) wurden thermografische Aufnahmen der jeweils lateralen Ansicht des Pferdekopfes aufgenommen sowie die genannten physiologischen Parameter bestimmt. Die aufgenommenen IR-Bilder wurden unter Berücksichtigung der anatomischen Strukturen des Pferdekopfes beurteilt, um geeignete Regions of Interest (ROIs) zu definieren. Die Beurteilung der Veränderung der Oberflächentemperaturverteilung erfolgte über die Berechnung von unilateralen Temperaturdifferenzen ( $\Delta \vartheta$ ) zwischen der maximalen Temperatur $\left(\vartheta_{\text {max }}\right)$ im Bereich des medialen Augenwinkels (ROI1) bzw. der Augenregion (ROI2) und den Durchschnittstemperaturen $\left(\vartheta_{m}\right)$ der ROIs (ROI1, ROI3-6), die über definierte vaskuläre Bahnen positioniert wurden. Es zeigte sich, dass im Verlauf der Belastung nach MZP3 einige der berechneten Temperaturdifferenzen signifikant kleiner wurden ( $\Delta \vartheta$ ROI6 und $\Delta \vartheta R O 15.3)$. ROI6, die Region arteria angularis occuli, zeigte einen instabilen Verlauf ( $\triangle$ YROI6) mit einer großen relativen Schwankungsbreite von $36 \%$. Dieser Messbereich befindet sich nach der Abzweigung der arteria dorsalis nasi aus der Endarterie arteria facialis. Die am ventralen Rand des Pferdekopfes und rostral des M. masseter gelegene ROI4 zeigte im Gegensatz dazu den stabilsten Verlauf $(\Delta \vartheta R O I 4)$ der Temperaturdifferenzen, eine geringe relative Schwankungsbreite von $8 \%$ und einen nichtsignifikanten $(0.8 \geq p \geq 0.2)$ Wilcoxon signed rank (multiple comparison test) über den gesamten Untersuchungszeitraum. Weitere Untersuchungen zur Erkennung von IR-Bilddetails am Kopf, die auf Schmerzen hinweisen können erscheinen sinnvoll.

Schlüsselwörter: Infrarot-Bildgebung / Pferdekopf / Kreislaufparameter / Thermographie / Laufband / bildgebende Diagnostik

Citation: Siewert C., Hellige M., Heuchert N., Rohn K., Stadler P., Seifert H. (2014) Effect of heart rate and respiratory rate on thermal infrared-imaging of the horse's head. Pferdeheilkunde 30, 521-530

Correspondence: Dipl.-Ing. Carsten Siewert, University of Veterinary Medicine Hannover Foundation, Institute of General Radiology and Medical Physics, Bischofsholer Damm 15, 30159 Hanover, Germany, E-Mail: carsten.siewert@tiho-hannover.de

\section{Introduction}

Thermal infrared imaging is a non-invasive method for twodimensional visualisation of surface temperature distributions of objects (Clark and Cena 1972, Turner et al. 1986, Diakides and Bronzino 2007). All warm-blooded mammals radiate infrared electromagnetic waves in the range of 4 to $20 \mu \mathrm{m}$ (Planck 1900, Bergmann and Schäfer et al. 1943). Previous veterinary studies on horses dealt mainly with hypotheses whether IR-imaging can be used for diagnostics of inflammations, blood vessel diseases, metabolic disorders, nerval disorders and neoplastic diseases. On horses IR-imaging was used in orthopaedic diagnosis (Schweinitz 1999, Turner 2001, Schulze 2004), recognition of the Horner syndrome (Purohit et al. 1979) and sinusitis (Krogbeumker et al. 2009, Siewert et al 
2011 , Krogbeumker et al. 2014). The reduction in the skin surface temperature caused by cold air passing through the nasal path was documented with IR-imaging (Siewert et al 2009) and calculated with a Finite Elements Method (Siewert et al 2011). The temperature distribution of a mammal depends on external parameters and patient-related parameters like surface properties like texture including fur and anatomical layers below the skin, subcutaneous tissue, perfusion, metabolic activity of the tissue and muscle activity (Turner et al. 1991, Siewert et al. 2011). Most of these parameters are included in the equation of biological heat conduction found by Pennes (1948), cf. chapter 'discussion'. Thus fundamental knowledge about anatomy and physiology of the anatomical region is essential for the diagnosis with IR-images. External parameters which have an influence on the surface temperature distribution are ambient temperature, air flow over the skin, radiation from the sun, certain light sources eg. halogen lamps and air humidity. In addition to the examination protocols used in human medicine (Saxena 2007, Diakides and Bronzino 2012, Vollmer and Möllmann 2010) for minimising the influence of those parameters the following recommendations have been established: Waiting time for a period of rest in the room before IR-images are taken, shutting out the day light in the examination room, ambient temperature below the temperature limit for perspiring. To make the interpretation of IR-images more independent concerning the influence of ambient temperature and measurement errors of the IRcamera there are two possibilities: I) Calculating temperature differences between saggital-symmetrical anatomical regions (Ford et al. 1997, Krogbeumker et al. 2009, Krogbeumker et al. 2014) within one IR-image matrix data set or II) Calculating unilateral temperature differences between an anatomical reference region and an anatomical target region within one IR-image matrix data set. However, unilateral temperature differences eg. between $\mathrm{RO}$ eyes and regions above blood vessels ( $\triangle$ ७ROI5.2 or $\Delta \vartheta R O l 6)$ are not independent of the ambient temperature (Siewert 2013).

In comparison with the central body region head and trunk in contrast - limbs had a higher physiological fluctuation range (Zapoudrina 2008). Consequently, Savary et al. (2008) found that the comparison of saggital symmetrical regions on porcine limbs with regard to the diagnosis of joint inflammations led to a higher percentage of false positive results (27-34\%) than the calculation of unilateral temperature dif-

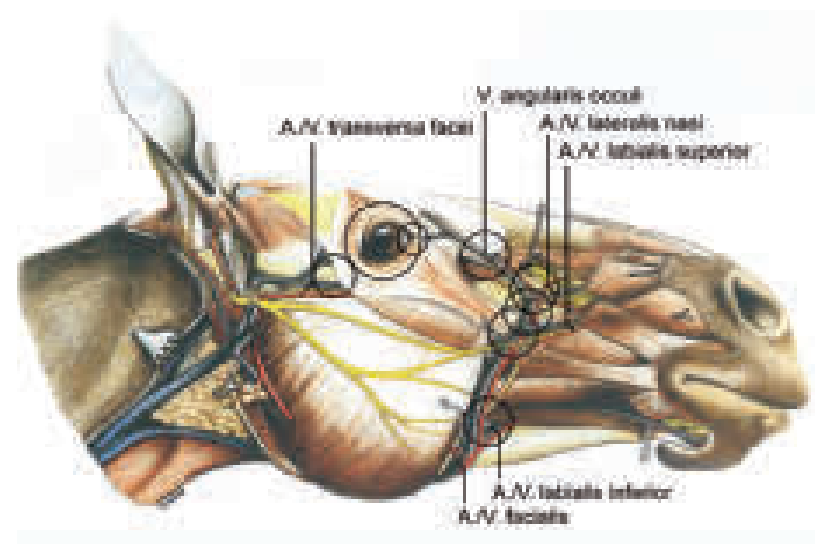

Fig. 1 Anatomical structures of the horse's head including position and size of the ROls, modified according to Budras et al. (2009). ferences between a reference area and an anatomical target area above the joint (2-23\%) within one IR-image.

Until now a largely unaddressed problem has arisen in the interpretation of IR findings regarding the influence of an increased heart rate (resulting in an increased blood perfusion) or respiratory rate caused by stress, fear or pain on the surface temperature distribution of a certain anatomical regions. The assessment of pain in horses by using physiological or endocrinological parameters is often insufficient because the heart- and respiratory rate can be influenced by excitement or fear (Meyer 1999).

A combination of physiological, endocrinological and ethological parameters has become more relevant for the definition of pain scales for horses especially in orthopaedic applications and in diagnosing the severity of colic (Bussières et al. 2008). Zierz (1993) used, besides physiological parameters ethological parameters such as non weight bearing on the lame or painful limb in opposite to the normal posture, expressing peripheral pain in the face "aching face", standing up, lying down, rolling the body on the ground to define a pain scale including grading of severity.

Bussières et al. (2008) examined these parameters on 18 horses with experimental pain induction and different treatment approaches regarding the reproducibility and sensitivity. While the physiological parameters had a moderate sensitivity, the ethological parameters (posture, restless stumping and scraping of hooves, kicking against the abdomen, unusually restless head movement) showed, besides good reproducibility a good sensitivity regarding pain detection.

The aim of this study is to investigate the effect of exercise on the treadmill on the temperature distribution of the lateral horse's head. An analytical method for IR-images of the lateral horse's head shall be developed which should be influenced as less as possible by blood and respiratory circulation

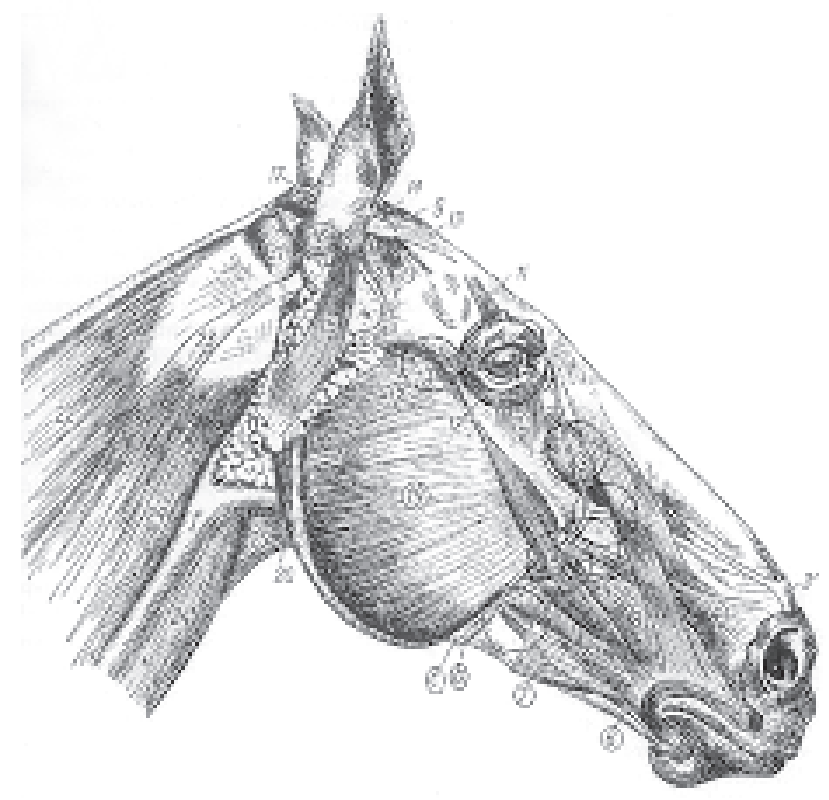

Fig. 2 Musculature of the horse's head, modified according to Nickel et al. (2001). 
parameters. The aim for future studies will be to use "painsensitive" anatomical regions (ROls) which are not influenced by circulatory parameters for detecting acute or chronic pain.

\section{Material and methods}

A thermal infrared camera type VarioCam ${ }^{\circledR}$ high resolution inspect (Fa. InfraTec, Dresden, Germany) was used for taking $I R$ images. The absolute accuracy of this IR camera is for an object temperature range $0-100^{\circ} \mathrm{C}$ specified by the manufacturer with $\pm 1.5^{\circ} \mathrm{C}$. The mean value of the measured detector inhomogeneity error of this $\mathbb{R}$ camera was $\sigma$ (standard deviation) $\approx 0.07^{\circ} \mathrm{C}$ (90 IR-images sequence of a black body reference radiator, (Siewert 2014)). This means practically that the thermal resolution within one infrared image data set or object is much higher than the large absolute measurement uncertainty $\left( \pm 1.5^{\circ} \mathrm{C}\right)$. In the present study any black body reference radiator with a precise temperature measurement could be used, because the anxious behaviour of the horse did not tolerate an unknown black cube close to the head. The thermal resolution is specified by the manufacturer with $50 \mathrm{mK}$ (Pre-

\begin{tabular}{ll}
\hline Table 1 & Evaluated ethological parameters. \\
\hline Posture & duration and type of unusual posture \\
& head- and tail position \\
& locomotion \\
& lifting of limbs was tolerated \\
\hline Behaviour & auscultation \\
& disquietness \\
& making sounds \\
& behaviour during the examination \\
\hline Facial & posture and movement of ears \\
& reaction on acoustical stimuli was present \\
& chape of nostrils and mouth region \\
& size of palpebral fissure, size of pupil
\end{tabular}

mium Mode). The IR camera which was used uses a microbolometer array matrix of $384 \times 288$ pixels as detector. The IR camera was switched on 15 min before taking medical IR images. It was not switched off during the experiment. For the horses fur an emissivity of 0.97 was assumed (Hassan et al. 2008, Vollmer et Möllmann 2010, Diakides and Bronzino 2012). IR images were evaluated with the image viewer software IRBIS ${ }^{\circledR}$-3plus (InfraTec, Dresden, Germany).

\section{Documentation of ambient parameters}

At the beginning of the thermographic examination of each horse the ambient temperature and air humidity were measured with a GMH 3330 and TFS 0100 E sensor (Greisinger electronic $\mathrm{GmbH}$, Regenstauf, Germany). During the examination the details in the room were recorded. Possible sources of disturbance (e.g. halogen lamp radiation, draught, radiation of the sun, thermal radiation of heaters) were documented and if possible avoided.

\section{Horse group for treadmill training}

For the study a group of 9 clinically inconspicuous non-lame warm-blooded horses (aged: 6.2 \pm 4.2 ) (3 geldings, 6 mares) from the Clinic for Horses (University of Veterinary Medicine, Hannover, Foundation) was used. All horses were similar in fur length. Before exercising on the treadmill the horses received a special orthopaedic examination and were lame-free.

Table 2 Definition of the relevant measuring time points (MTP) and parameters of the treadmill protocol.

\begin{tabular}{ll}
\hline Measuring time point & Definition \\
\hline MTP1 & before exercise \\
MTP2 & after 10 min training in step $(1.5 \mathrm{~m} / \mathrm{s})$ \\
MTP3 & after 5 min slow trot $(2.7 \mathrm{~m} / \mathrm{s})$ \\
MTP4 & after 5 min fast trot $(3.6 \mathrm{~m} / \mathrm{s})$ \\
\hline
\end{tabular}
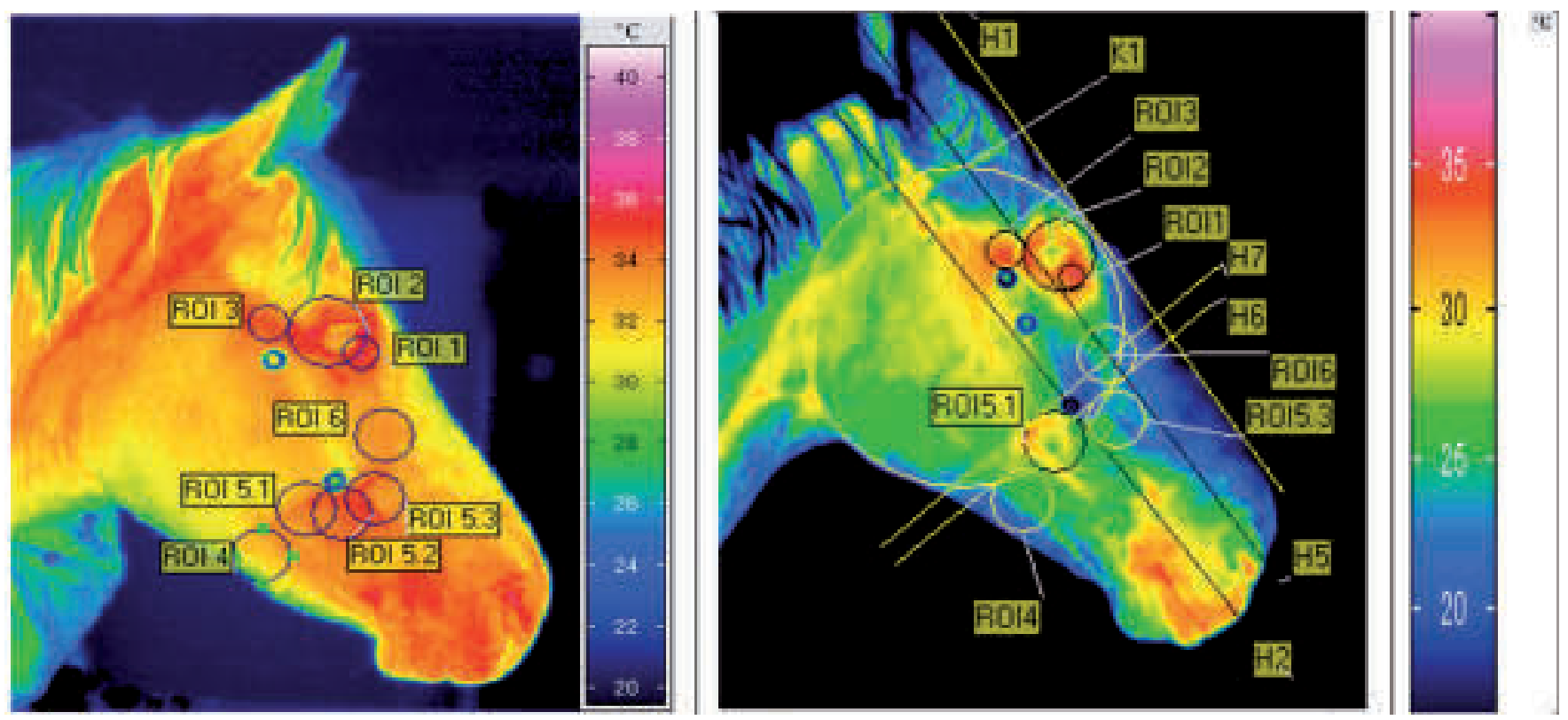

Fig. $3 \mathrm{a}, \mathrm{b}$ Construction of the ROls (black) in the IR-image, mare, 6 years of age, ambient temperature $16.2^{\circ} \mathrm{C}, \mathrm{RH} 36.2 \%$. 


\section{Experimental Procedure}

Recording of ethological and physiological parameters and taking IR-images was carried out with all horses in the same room under similar ambient conditions (ambient temperature: $18.2 \pm 1.9^{\circ} \mathrm{C}$, relative air humidity: $34.3 \pm 3.7 \%$, without direct radiation from sun light). The resting time (acclimatisation period) before the training in the examination room was $10 \mathrm{~min}$. The name, age, breed, gender, colour of fur, changes of fur colour in the relevant region were documented. During the resting state the heart rate ((HR), measured with auscultation), respiratory rate (RR), body core (rectal) temperature $(C T)$ were measured and nutritional status, respiratory type and nasal discharge recorded. During the acclimatisation phase and exercise period on the treadmill ethological parameters which would indicated pain were verified (s. Tab. 1). Digital photos were made to record possible 'artefacts' in the IR-images (scars, sore places, marks, fur inhomogenities, dirt in the fur).

For an improved anatomical orientation in the often low-contrasted IR-images two aluminium washers (diameter $=20 \mathrm{~mm}$ ) were attached at the crista facialis (Fig. 3a).

At the beginning IR images of lateral views of the horse's head were taken at measuring time point 1 ((MTP1), cf. Tab. 2) and physiological parameters like heart rate, respiratory rate and body core temperature (rectal temperature) were measured.
Then the horses were exercised for 10 minutes walking in step $(1.5 \mathrm{~m} / \mathrm{s})$ on the treadmill model 2200 Mustang (Fa. Kagra, Gruber AG, Switzerland). During the subsequent short interruption of the training programme, the physiological parameters were measured again and lateral IR-images were taken (MTP2, cf. Tab. 2). After applying the bridle and an adaption period of 1-2 min walking in the step, the horses were trained in the slow trot for $5 \mathrm{~min}(2.7 \mathrm{~m} / \mathrm{s})$ on the treadmill. Then the same procedure was carried out again (MTP3) and after 5 min in the fast trot $(3.6 \mathrm{~m} / \mathrm{s})$ a last time (MTP4).

\section{Evaluation of IR images}

The positions of the ROls were defined by anatomical specimens on the basis of blood vessels and facial muscles compared to IR images (see Fig. 1 and 2), (Fleischmann 2009). The radiuses of $\mathrm{ROI} 4$, $\mathrm{ROI} \mathrm{5.1,5.2,} \mathrm{5.3,} \mathrm{ROI} 6$ ) are thus proportionally reduced to $1 / 2$ of the distance between $\mathrm{H} 1$ and $\mathrm{H} 2$ cf. Fig. 3. The reference line $\mathrm{H} 1$ touches the dorsal head contour and a parallel line $\mathrm{H} 2$ is defined by the rostral end of the crista facialis marked with a thin aluminium washer (diameter $=20 \mathrm{~mm}$ ). The diameter of circle $\mathrm{K} 1$ multiplied by three scaling factors $(0.102 ; 0.235 ; 0.132)$ are defining the diameters of ROI1, ROI2 and ROI3. To minimise the systematic absolute measurement error of the $\mathrm{IR}$ camera $\left( \pm 1.5^{\circ} \mathrm{C}\right)$ (Infratec $\mathrm{GmbH}$, operating manual) and to achieve a minor relationship on the ambient temperature, temperature diffe-

Table 3 Anatomical structures within the ROls.

\begin{tabular}{ll}
\hline Definition of ROls & Anatomical target region \\
\hline ROI 1 & medial corner of the eye (canthus) \\
ROI 2 & region around the eye including both corners of the eye \\
ROI 3 & arteria/vena transversa facei, muscle masseter \\
ROI 4 & $\begin{array}{l}\text { arteria/vena facialis et arteria/vena labialis inferior, muscle depressor labii inferioris, muscle cutaneus faciei, } \\
\text { muscle masseter }\end{array}$ \\
ROI 5.1, ROI 5.2, ROI 5.3 & $\begin{array}{l}\text { arteria/vena facialis et arteria/vena labialis superior et arteria/vena lateralis nasi, muscle levator nasolabialis, } \\
\text { muscle lebator labii superioris, muscle caninus, muscle zygomaticus, muscle buccinator } \\
\text { ROI } 6\end{array}$ \\
\hline
\end{tabular}

Table 4 Median values, minimum, maximum, range of 4 median values and relative percent range of variation of the temperature differences for the relevant MTP in the IR-image.

\begin{tabular}{|c|c|c|c|c|c|c|c|}
\hline & $\begin{array}{c}\vartheta_{\max }(\mathrm{ROI} 2)- \\
\vartheta_{\mathrm{m}}(\mathrm{ROI} 1) \\
{\left[{ }^{\circ} \mathrm{C}\right]}\end{array}$ & $\begin{array}{c}\vartheta_{\max }(\mathrm{ROI} 1)- \\
\vartheta_{\mathrm{m}}(\mathrm{ROI} 3) \\
{\left[{ }^{\circ} \mathrm{C}\right]}\end{array}$ & $\begin{array}{c}\vartheta_{\max }(\mathrm{ROI} 1)- \\
\vartheta_{\mathrm{m}}(\mathrm{RO} / 4) \\
{\left[{ }^{\circ} \mathrm{C}\right]}\end{array}$ & $\begin{array}{c}\vartheta_{\max }(\mathrm{ROI} 1)- \\
\vartheta_{\mathrm{m}}(\mathrm{ROI} 5.1) \\
{\left[{ }^{\circ} \mathrm{C}\right]}\end{array}$ & $\begin{array}{c}\vartheta_{\text {max }}(R O I 1)- \\
\vartheta_{m}(R O I 5.2) \\
\quad\left[{ }^{\circ} \mathrm{C}\right]\end{array}$ & $\begin{array}{c}\vartheta_{\text {max }}(\mathrm{ROI} 1)- \\
\vartheta_{\mathrm{m}}(\mathrm{ROI} 5.3) \\
\quad\left[{ }^{\circ} \mathrm{C}\right]\end{array}$ & $\begin{array}{c}\vartheta_{\max }(\mathrm{ROI} 1)- \\
\vartheta_{\mathrm{m}}(\mathrm{RO} \mid 6) \\
{\left[{ }^{\circ} \mathrm{C}\right]}\end{array}$ \\
\hline Abbreviation & $\Delta \vartheta \mathrm{ROI} 1$ & $\Delta \vartheta \mathrm{ROI} 3$ & $\Delta \vartheta \mathrm{ROI} 4$ & $\Delta \vartheta \mathrm{ROI}^{2} .1$ & $\Delta \vartheta \mathrm{ROI5.2}$ & $\Delta \vartheta \mathrm{ROI5.3}$ & $\Delta \vartheta \mathrm{ROI6}$ \\
\hline MTP1 & $\begin{array}{c}1.6 \\
(0.9-2.1)\end{array}$ & $\begin{array}{c}2.3 \\
(0.7-3.8)\end{array}$ & $\begin{array}{c}5.0 \\
(3.8-6.9)\end{array}$ & $\begin{array}{c}3.4 \\
(1.5-5.3)\end{array}$ & $\begin{array}{c}2.7 \\
(0.9-4.6)\end{array}$ & $\begin{array}{c}3.8 \\
(2.8-5.3)\end{array}$ & $\begin{array}{c}5.2 \\
(3.4-6.5)\end{array}$ \\
\hline MTP2 & $\begin{array}{c}1.4 \\
(0.9-2.4)\end{array}$ & $\begin{array}{c}2.4 \\
(0.9-3.6)\end{array}$ & $\begin{array}{c}5.2 \\
(3.1-7.2)\end{array}$ & $\begin{array}{c}3.5 \\
(0.9-5.2)\end{array}$ & $\begin{array}{c}2.8 \\
(0.6-4.4)\end{array}$ & $\begin{array}{c}3.6 \\
(1.1-4.7)\end{array}$ & $\begin{array}{c}4.6 \\
(1.7-5.7)\end{array}$ \\
\hline MTP3 & $\begin{array}{c}1.3 \\
(0.9-2.0)\end{array}$ & $\begin{array}{c}2.2 \\
(0.8-2.9)\end{array}$ & $\begin{array}{c}4.8 \\
(3.0-10.7)\end{array}$ & $\begin{array}{c}3.2 \\
(1.3-4.6)\end{array}$ & $\begin{array}{c}2.7 \\
(1.5-4.1)\end{array}$ & $\begin{array}{c}3.0 \\
(2.1-4.4)\end{array}$ & $\begin{array}{c}3.6 \\
(2.6-5.5)\end{array}$ \\
\hline MTP4 & $\begin{array}{c}1.5 \\
(0.8-2.0)\end{array}$ & $\begin{array}{c}2.2 \\
(1.1-4.1)\end{array}$ & $\begin{array}{c}5.0 \\
(3.7-7.8)\end{array}$ & $\begin{array}{c}3.5 \\
(2.2-5.8)\end{array}$ & $\begin{array}{c}3.2 \\
(2.0-5.1)\end{array}$ & $\begin{array}{c}3.6 \\
(2.5-4.9)\end{array}$ & $\begin{array}{c}4.3 \\
(2.3-5.7)\end{array}$ \\
\hline $\begin{array}{l}\text { Ra } 4 \mathrm{~m}=\text { range of } 4 \text { median values } \\
(\mathrm{MTP} 1 \ldots 4)\end{array}$ & 0.3 & 0.2 & 0.4 & 0.3 & 0.5 & 0.8 & 1.6 \\
\hline $\begin{array}{l}\text { Relative percent range }:= \\
\text { Ra } 4 \mathrm{~m} / \text { averaged medians } \\
(\text { MTP1 ...4) }\end{array}$ & $20.7 \%$ & $8.8 \%$ & $8.0 \%$ & $8.8 \%$ & $17.5 \%$ & $22.8 \%$ & $36.1 \%$ \\
\hline
\end{tabular}


rences $(\Delta \vartheta)$ similar to former studies (Siewert et al. 2010) were defined between reference regions with maximum values and average temperatures defined by target ROls (cf. Tab. 3) according to eq. $(1,2)$.

$$
\begin{aligned}
& \Delta \vartheta \mathrm{ROI}_{1}:=\vartheta_{\text {max,ROI } 2}-\vartheta_{\text {m,ROI } 1} \\
& \Delta \vartheta \operatorname{ROI}, \ldots, 6:=\vartheta_{\text {max }, \mathrm{ROI} 1}-\vartheta_{\mathrm{m}, \mathrm{ROI} 3, \ldots, 6}
\end{aligned}
$$

Based on the results of the study by Stewart et al. (2008) and observations from our own preliminary experiments (Fleischmann et al. 2009) certain regions were used, because temperature values around the eyes were considered to be relatively stable. As a thermal reference value, the maximum temperature value of the medial corner of the eye (canthus) $\vartheta_{\text {max }}(R O I 1)$ or the region around the eye $\vartheta_{\text {max }}(\mathrm{ROI} 2)$ were defined. For the target regions, the average temperatures of the $\mathrm{ROls}$ $\left(\vartheta_{m}\right.$ ROI $3 \ldots \vartheta_{m}$ ROI 6) were used for detecting the changes resulting from increased muscle activity, increased blood flow or respiratory rate due to increased exercise. Furthermore the range of ambient temperature was limited to $18.2 \pm 1.9^{\circ} \mathrm{C}$. One horse had on the right head side a skin defect or abnormality of the skin and has been affected in the region ( $R O / 3$ ). It was therefore not evaluated in this region. This horse did not allow at any time to measure the rectal body temperature.

\section{Statistical analysis of the results}

The statistical evaluation of the results was performed using the SAS program (version 9.2, SAS Institute Inc., Cary, NC, USA). An examination of the quantitative proband group data by visual assessment of QQPlots did not confirm a Gaussian normal distribution curve for all data. Thus, nonparametrical statistical tests were chosen and the correlation coefficient according to Spearman had to be taken. For the descriptive statistics median, minimum, maximum, range of 4 medians and the relative percent range of variation of the temperature differences $\Delta \vartheta R O I 3 . .6$ over the target regions were calculated at the measuring time points MTP1, MTP2, MTP3 and MTP4, respectively. The change in temperature differences within the timespan between paired samples was tested using a Wilcoxon signed rank (multiple comparison) test.

To assess the statistical relationships of heart rate increase $(\Delta H R)$, respiratory rate increase $(\Delta R R)$ and body core temperature increase $(\Delta C T)$ to the temperature differences the correlation coefficient $r_{s}$ according to Spearman was calculated. Furthermore a linear regression analysis, to the temperature differences was calculated with the physiological parameters $\Delta H R$ and $\Delta R R$ as predictor variables.

\section{Results}

The structuring is based on the stability of the ROls starting with $\triangle$ VROI4.

\section{Classification I: $\Delta \vartheta R O / s$ stable - minor changes}

$\Delta \vartheta \mathrm{RO}$ 4: Most stable with minor changes in the temperature difference

A time-dependent course with a stable characteristics especially the smallest relative percent range of variation with $8 \%$ (cf. Tab. 4) was present during the duration of the experiment on

\begin{tabular}{|c|c|c|c|c|c|c|c|}
\hline & $\begin{array}{c}\vartheta_{\max }(\mathrm{ROI} 2)- \\
\vartheta_{\mathrm{m}}(\mathrm{ROI}) \\
{\left[{ }^{\circ} \mathrm{C}\right]}\end{array}$ & $\begin{array}{c}\vartheta_{\max }(\mathrm{ROI} 1)- \\
\vartheta_{\mathrm{m}}(\mathrm{ROI}) \\
{\left[{ }^{\circ} \mathrm{C}\right]}\end{array}$ & $\begin{array}{c}\vartheta_{\max }(\mathrm{ROI} 1)- \\
\vartheta_{\mathrm{m}}(\mathrm{ROI}) \\
{\left[{ }^{\circ} \mathrm{C}\right]}\end{array}$ & $\begin{array}{c}\vartheta_{\max }(\mathrm{ROI} 1)- \\
\vartheta_{\mathrm{m}}(\mathrm{ROI} 5.1) \\
{\left[{ }^{\circ} \mathrm{C}\right]}\end{array}$ & $\begin{array}{c}\vartheta_{\text {max }}(\mathrm{ROI} 1)- \\
\vartheta_{\mathrm{m}}(\mathrm{ROI} 5.2) \\
{\left[{ }^{\circ} \mathrm{C}\right]}\end{array}$ & $\begin{array}{c}\vartheta_{\max }(\mathrm{ROI} 1)- \\
\vartheta_{\mathrm{m}}(\mathrm{ROI} 5.3) \\
{\left[{ }^{\circ} \mathrm{C}\right]}\end{array}$ & $\begin{array}{c}\vartheta_{\max }(\mathrm{ROI} I)- \\
\vartheta_{\mathrm{m}}(\mathrm{ROI}) \\
{\left[{ }^{\circ} \mathrm{C}\right]}\end{array}$ \\
\hline Abbreviation & $\Delta \vartheta R O I 1$ & $\Delta \vartheta \mathrm{ROI}$ & $\Delta \vartheta \mathrm{ROI} 4$ & $\Delta \vartheta \mathrm{ROI5.1}$ & $\Delta \vartheta \mathrm{ROI5.2}$ & $\Delta \vartheta \mathrm{ROI} 5.3$ & $\triangle 9 R O I 6$ \\
\hline MTP1-MTP2 & 0.421 & 0.831 & 0.811 & 0.420 & 0.435 & 0.039 & 0.001 \\
\hline MTP1-MTP3 & 0.025 & 0.309 & 0.199 & 0.053 & 0.184 & 0.001 & 0.000 \\
\hline MTP1-MTP4 & 0.157 & 0.586 & 0.513 & 0.184 & 0.031 & 0.127 & 0.004 \\
\hline
\end{tabular}

Table 5 p-values of the Wilcoxon signed rank (multiple comparison) for temperature differences between MTP1 and further MTPs.

Wilcoxon signed rank (multiple comparison) Statistical significant $(0.001<p<0.05)$ in grey, statistical highly significant $(p<0.001)$ in dark grey

\begin{tabular}{|c|c|c|c|c|c|c|c|}
\hline & $\begin{array}{c}\vartheta_{\max }(R O \mid 2)- \\
\vartheta_{\mathrm{m}}(\mathrm{ROI}) \\
{\left[{ }^{\circ} \mathrm{C}\right]}\end{array}$ & $\begin{array}{c}\vartheta_{\max }(\mathrm{ROI} 1- \\
\vartheta_{\mathrm{m}}(\mathrm{ROI}) \\
{\left[{ }^{\circ} \mathrm{C}\right]}\end{array}$ & $\begin{array}{c}\vartheta_{\max }(\mathrm{RO} \mid 1)- \\
\vartheta_{\mathrm{m}}(\mathrm{RO} \mid 4) \\
{\left[{ }^{\circ} \mathrm{C}\right]}\end{array}$ & $\begin{array}{c}\vartheta_{\max }(\mathrm{ROII})- \\
\vartheta_{\mathrm{m}}(\mathrm{ROI} 5.1) \\
{\left[{ }^{\circ} \mathrm{C}\right]}\end{array}$ & $\begin{array}{c}\vartheta_{\max }(\mathrm{ROI})- \\
\vartheta_{\mathrm{m}}(\mathrm{ROI} 5.2) \\
{\left[{ }^{\circ} \mathrm{C}\right]}\end{array}$ & $\begin{array}{c}\vartheta_{\max }(\mathrm{ROI} 1)- \\
\vartheta_{\mathrm{m}}(\mathrm{ROI} 5.3) \\
{\left[{ }^{\circ} \mathrm{C}\right]}\end{array}$ & $\begin{array}{c}\vartheta_{\max }(\mathrm{ROI} 1)- \\
\vartheta_{\mathrm{m}}(\mathrm{ROI}) \\
{\left[{ }^{\circ} \mathrm{C}\right]}\end{array}$ \\
\hline Abbreviation & $\Delta \vartheta \mathrm{ROI}$ & $\Delta \vartheta \mathrm{ROI}$ & $\triangle \vartheta \mathrm{ROI} 4$ & $\Delta \vartheta \mathrm{ROI} 5.1$ & $\Delta \vartheta \mathrm{ROI5.2}$ & $\Delta \vartheta R O I 5.3$ & $\Delta \vartheta \mathrm{ROI6}$ \\
\hline$r_{s}(\Delta H R)$ & -0.09 & 0.17 & -0.13 & -0.08 & 0.05 & -0.23 & -0.68 \\
\hline$p$-value & 0.72 & 0.51 & 0.61 & 0.75 & 0.85 & 0.36 & 0.002 \\
\hline$r_{s}(\Delta R R)$ & 0.12 & 0.33 & 0.24 & 0.033 & 0.04 & 0.5 & 0.36 \\
\hline$p$-value & 0.6 & 0.19 & 0.34 & 0.89 & 0.88 & 0.035 & 0.14 \\
\hline$\Delta \mathrm{CT}, \mathrm{p}$-value & 0.25 & 0.71 & 0.25 & 0.65 & 0.42 & 0.43 & 0.80 \\
\hline
\end{tabular}

Table 6 Correlation coefficients according to Spearman to $\triangle H R, \triangle R R, \triangle C T$; MTPI,3.

correlation coefficient $r_{s}$ (Spearman; MTP1,3): statistical significant marked in grey $(0.001<p \leq 0.05)$

Table 7 Multiple regression analysis to $\Delta H R, \Delta R R$ with coefficients of determination MTPI,3

\begin{tabular}{lccccccc}
\hline Abbreviation & $\Delta \vartheta \mathrm{ROI1}$ & $\Delta \vartheta \mathrm{ROI3}$ & $\Delta \vartheta \mathrm{ROI4}$ & $\Delta \vartheta \mathrm{ROI5.1}$ & $\Delta \vartheta \mathrm{ROI5.2}$ & $\Delta \vartheta \mathrm{ROI5.3}$ & $\Delta \vartheta \mathrm{ROI6}$ \\
\hline coefficient of determination $\mathrm{R}^{2}$ & 0.03 & 0.14 & 0.066 & 0.03 & 0.01 & 0.25 & 0.60 \\
p-value & 0.80 & 0.35 & 0.60 & 0.79 & 0.92 & 0.12 & 0.001 \\
\hline
\end{tabular}

Multiple regression analysis $(\Delta \mathrm{HR}, \Delta \mathrm{RR} ; \mathrm{MTP1}, 3)$ : significant $(0.001<\mathrm{p}<0.05)$ marked in grey 
$\Delta$ YROI4 (cf. Tab. $4-7$ ). This result was consistent with not significant $p$-values ( $p \geq 0.2$; Wilcoxon signed rank (multiple comparison) test) (cf. Tab. 5) during the duration of the training. The correlation test according to Spearman was not significant with the parameters heart rate $\left(p>0.60, r_{s}=-0.13\right)$ and respiratory rate $\left(p>0.34, r_{s}=0.24\right)$. This test is consistent to a not significant result of the multiple regression analysis.

\section{$\Delta$ ӨROI3: Very stable}

$\Delta$ YROI3 (cf. Tab. 4-7) has the same classification as $\Delta \vartheta R O \mid 4$. A very small relative percent range of variation with $8.8 \%$ (cf. Tab. 4). This result was consistent with not significant $p$-values ( $p \geq 0.3$; Wilcoxon signed rank (multiple comparison) test) (cf. Tab. 5), a not significant correlation test according to Spearman with the parameters heart rate and respiratory rate $(p \geq 0.19)$ (cf. Tab. 6) and a not significant result of the multiple regression analysis $(p \geq 0.35)$ (cf. Tab. 7).

\section{Classification II: Final statement impossible - neither stable} nor instable

$\Delta$ ӨROI5. 1: Neither stable nor instable - rather stable

$\Delta \vartheta \mathrm{RO} 5.1$ has a small relative percent range of variation with $8.8 \%$ (Tab. 4) which is consistent to nonsignificant $p$-values ( $p>0.18)$ between MTP2-1 or MTP4-1 (Tab. 5) but not consistent to a $p$-value lying on the significance threshold ( $p=0.053$ ) at MTP3-1 (Tab. 5). Spearman's correlation coefficients to the heartrate and respiratory rate were not significant $(p>0.7)$ (Tab.7). Spearman's test is consistent with the nonsignificant coefficient of determination $\left(R^{2}=0.03\right.$, $p=0.79)$, (Tab. 7).

$\Delta$ ७ROI5.2: Neither stable nor instable - more stable compared to $\Delta \vartheta \mathrm{ROI} 5.3$ and $\Delta \vartheta \mathrm{ROI} 6$

$\triangle$ YROI5.2 has a relative percent range of variation with $17.5 \%$ (Tab. 4) which is consistent with a significant $p$-value $(p=0.03)$ at MTP4- 1 (Tab. 5). However Spearman's correlation coefficients to the heartrate and respiratory rate were not significant ( $p>0.8)$ (Tab. 6). Spearman's test is consistent with the insignificant coefficient of determination $\left(R^{2}=0.01\right.$, $p=0.92)$, (Tab. 7).

$\Delta \vartheta R O I 1:$ Neither stable nor instable - rather instable

$\Delta \vartheta R O I 1$ has a relative percent range of variation with $20.7 \%$ and the reduction in the temperature difference was significant $(p=0.025)$ between (MTP1-3) with Wilcoxon signed rank (multiple comparison) test but not between (MTP1-2) or (MTP1-4). Besides, no significant correlation (Tab. 6) or multiple regression analysis (Tab. 7) occurred with the parameters heart rate $(\Delta H R)$ or respiratory rate $(\Delta R R)$.

\section{Classification III: $\Delta \vartheta R O / s$ instable - major changes}

\section{$\Delta \vartheta \mathrm{ROI}, \Delta \vartheta \mathrm{ROI} 5.3$}

$\Delta \vartheta \mathrm{ROI} 6$ has the largest relative percent range of variation with $36.1 \%$ (Tab. 4). The reduction in the temperature difference was significant ( $\mathrm{p} \leq 0.001)$ with Wilcoxon signed rank (multiple comparison) test for $\triangle$ YROI5.3 and $\triangle \vartheta$ ROI6 between MTP3 and MTP1 (Tab. 5). $\triangle$ VROI6 is the only one temperature difference which has significant $p$-values $(p<0.008)$ between MTP2 and MTP1 (Tab. 5). A significant correlation according to Spearman occurred with the parameter heart rate $\left(p<0.002, r_{s}=-0.68\right)$, (Tab. 6). This test is consistent with a significant result of the multiple regression analysis (coefficient of determination): $R^{2}=0.60$; predictor variables: $\Delta H R, \Delta R R$ ), (Tab. 7$)$. $\Delta \vartheta R O l 6$ had a large coefficient of determination compared to the other temperature differences and a significant $p$-value $(p=0.001$; group range $\Delta$ YROI1-6: $p$ was between 0.001-0.92, median value 0.6, (Tab. 7). The multiple regression analysis of $\Delta \vartheta \mathrm{ROI5.3}$ is not consistent $(p=0.12)$ with the significant correlation according to Spearman of the parameter respiratory rate $\left(p<0.035, r_{s}=0.5\right)$ and two significant Wilcoxon signed rank tests (Tab. 5).

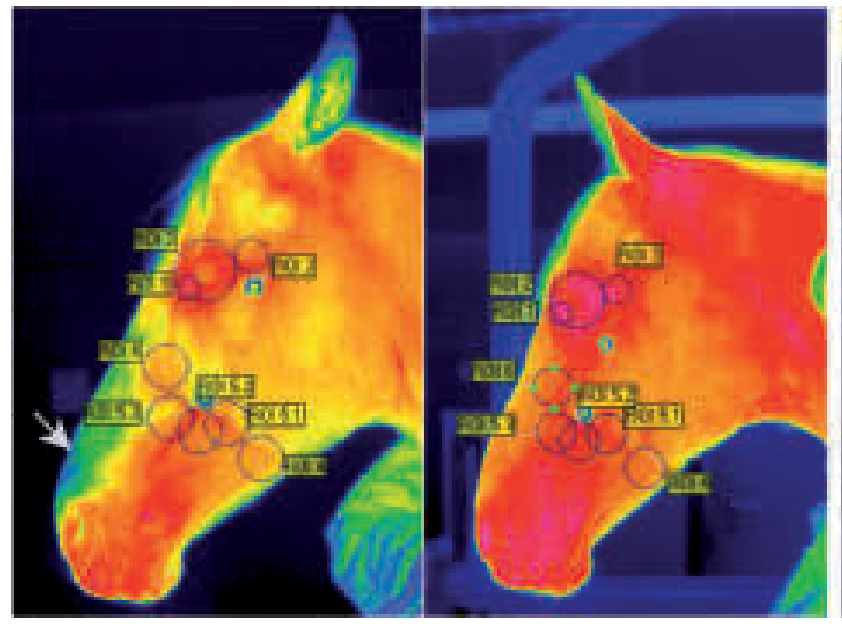

MTP1
MTP2

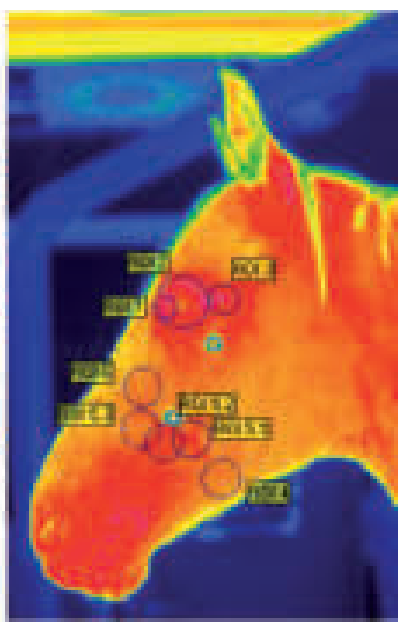

MTP3

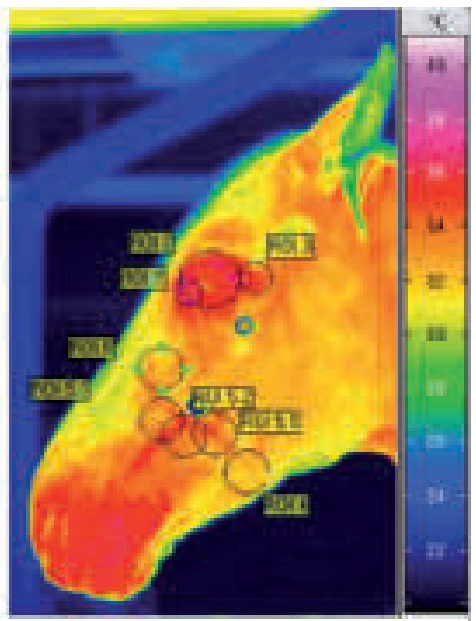

MTP4

Fig. 4 IR-image series with marked ROls, Hannoveraner, mare, 6 years of age, ambient temperature $18.2{ }^{\circ} \mathrm{C}$, RH $35.1 \%$. 


\section{Discussion}

In contrast to the investigation of orthopaedic diagnostic applications, especially inflammation of joints, only few studies which are dealing with IR-thermography for diagnostics at the horse's head exist.

Regulation of the skin perfusion by the autonomic nervous system

Purohit et al. (1979) analysed the diagnostic value of infrared imaging in relation to the Horner-syndrome, a one-sided miosis, with drooping of the upper eyelid, one-sided enophthalamus and local skin temperature rise $\left(1-2.5^{\circ} \mathrm{C}\right)$ caused by a nerval damage to the vasosympathetic trunk followed by a vasodilatation. The diagnostic with IR-imaging was helpful.

\section{Minimising of measurement error of IR camera}

The comparison of surface temperatures between anatomical symmetrical regions, which cannot be included on one single IR-image because the region is located on the opposite body side (e.g. the lateral angle of the eye) requires an evaluation method which minimises the measurement error (drift error) of the IR camera. This requirement is fulfilled with the difference-ROl-method (Siewert et al. 2010 and 2014). Which uses temperatures of thermal stabile regions (eg. temperature of region around the eyes) and anatomical target areas with subsequent difference calculation.
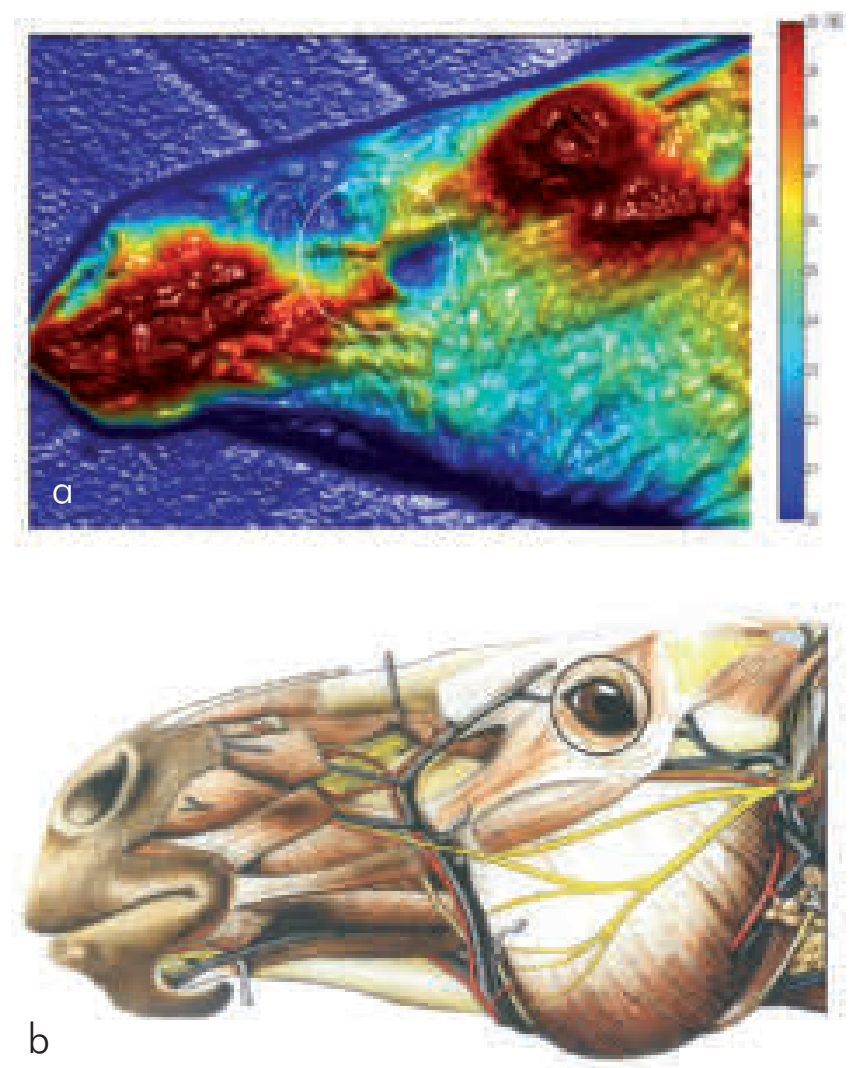

Fig. 5 a: Processed lateral IR-image after applying relief-method according to Siewert 2009 taken from (Fleischmann and Siewert 2009). b: Anatomy of the horse's head modified according to Budras et al. (2009)
Disadvantageous effect of ambient temperature on unilateral temperature differences

With the calculation of temperature differences the disadvantageous effect of the ambient temperature should be reduced. In spite of this - a significant relationship on the ambient temperature remains, even though unilateral temperature differences were measured at the horse's head ( $n=40$ head sides, healthy control group in an ambient temperature range $\vartheta_{\mathrm{A}}: 5-20^{\circ} \mathrm{C}$, eq. 3,4 (Siewert et al. 2013):

$$
\begin{aligned}
& \Delta \text { ソROI5.2 - } 0.41 \vartheta_{\text {A with }}\left(r_{s}=-0.73, p=0.000\right) \\
& \Delta \vartheta R O 16 \sim-0.33 \vartheta_{A} \text { with }\left(r_{s}=-0.76, p=0.000\right)
\end{aligned}
$$

Even a significant correlation $(p=0.02)$ to the fur length exist to $\Delta$ YROI5.2 and $\Delta$ VROI6 $(p=0.045)$ tested with a correlation according to Spearman ( $n=22$ head sides) (Siewert et al 2013). This means that a rise in ambient temperature of only $1^{\circ} \mathrm{C}$ causes a typical decrease of the unilateral temperature differences of -0.41 respectively $-0.33^{\circ} \mathrm{C}$

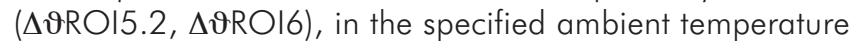
range (Siewert et al. 2013) if the same length in fur is guaranteed. The knowledge of the effect of the ambient temperature on each temperature difference (eq. 1,2) is - when comparing IR-findings of different individual animals - of importance, because in practice in most cases no climatecontrolled examination room is available and the range of the ambient temperature is not as narrow as in the present study $\left(18.2 \pm 1.9^{\circ} \mathrm{C}\right)$. A requirement is that stable $\mathrm{ROls}$ are not located above the nasal air path because a cooling down as a function depending on the temperature of the inhaled air has to be expected as finite elements calculations (Siewert et al. 2011) and IR-studies at the horse's head (Krogbeumker 2009) confirm. This effect can be seen in Fig. 4 (MTP1, see white arrow) and even better on an IR-image processed by relief method taken on a lower ambient temperature Fig. $5 a$.

\section{Biological heat equation}

For interpreting IR-images of the horse's head it is essential to determine the biological fluctuation range, particularly to evaluate the heart rate as the blood perfusion rate $\omega$ is an important factor in the second term of the biological heat conduction equation (eq. 5) (Pennes 1948). $\omega / \omega_{\text {relax }}=1 \ldots 10$

$$
\nabla k \nabla T+\omega \rho_{b} c_{b}\left(T_{b}-T\right)+Q_{m}=0
$$

The Nabla operator $(\nabla)$ is a vector differential operator:

$$
\nabla=(\partial / \partial x, \partial / \partial y, \partial / \partial z)
$$

Constants: $\rho_{b}$ and $c_{b}$ are the density and the specific heat of the blood (Gonzalez 2007) and are practically constants in the ambient temperature range $\left(14-22{ }^{\circ} \mathrm{C}\right)$ and a constant blood temperature is defined by $T_{b}$. Cell metabolism produces heat, which is included in the parameter $Q_{m}$ defined as metabolic heat.

Parameters: $k$ is the thermal conductivity of the respective tissue. Subcutaneous fat tissue has a thermal conductivity of $\mathrm{k}=0.16-0.2 \mathrm{Wm}^{-1} \mathrm{~K}^{-1}$ and muscle tissue approx. $\mathrm{k}=0.42$ 
$\mathrm{Wm}^{-1} \mathrm{~K}^{-1}$ (Zheng 1990). Consequently, $\mathrm{k}_{\text {muscle }}$ is approx. twice as high as the value in subcutaneous fat tissue. $T$ is the local tissue temperature.

The solution of eq. 5 for calculating temperature profiles in the tissue is possible by application of the Finite Elements Method (FEM) (Gonzalez 2007, Siewert et al. 2010b, Siewert et al. $2011)$. Investigating the effects of heart rate and respiratory rate is essential: To investigate the effects of increased blood flow (second term eq. 5) and respiratory circulatory parameters on the IR-image of the horse's head, a treadmill was used.

Hypothalamos adjustment control for body core temperature and heat dissipation

Thermoregulation in mammals (all homoithermal beings) is controlled by the hypothalamos resulting in a narrow body core temperature range. The produced heat is transferred by means of short-term thermoregulatory mechanisms, e.g. through increased perfusion of the subcutaneous tissue and heat dissipation through the skin to the ambient air (von Engelhardt and Breves 2010). The macroscopic analysis of the temperature distribution of an IR-image sequence of a horse to the chosen measurement timepoints (cf. Fig. 4, MTP1-MTP3) shows the warming of large regions of the lateral horse's head caused by the physiological regulation processes. Especially the regions around the eyes and nostrils are affected (Purohit et al. 1979). This former finding was based on a small group of 6 horses before and after exercise on a treadmill.

\section{Effect of adrenaline caused by stress, pain or excitement}

A logical explanation for a change in the temperature in the region of the eye is the activation of the hypophysis-hypothalamos-adrenal glands-axis e.g. caused by stress with adrenaline subsequently being liberated into the blood plasma causing a vasoconstriction of blood vessels in the brain (Thews and Mutschler et al 2007).

Stewart et al. (2007) used the regulatory function of this system and exposed cows to different biochemical substances (intravenous application of $\mathrm{ACTH}, \mathrm{CRH}$, adrenaline), stressors like social isolation and examined the change in the maximum temperature of the eye in the region of the lacrimal sack located at the medial angle of the eye.

For verifying the effect of the vasosympathetic autonomous nerval system on the maximum temperature of the region (medial angle of the eye) calves $(n=16)$ received an infusion of adrenaline or physiological saline solution (Stewart 2008, $\mathrm{PhD}$ thesis). A significant decrease $\left(1.4^{\circ} \mathrm{C}, \mathrm{p}=0.01\right)$ in the maximum temperature in the region lacrimal sac caused by an adrenaline infusion compared to the maximum temperature before infusion was observed. The explanation for this temperature drop is plausible but cannot be regarded as finally proven because it is not known if the drift error of the IR-camera (Siewert 2014) was determined during Stewart's experiment. This absolute measurement error can vary depending on the type of IR camera, the sensor type (Chrzanowski 2001, Hartmann 2001), ambient temperature and duration of the measurement. If the duration of the IR-image sequence is, for exam- ple $15 \mathrm{~min}$ the drift error can be approx. $1.2-2{ }^{\circ} \mathrm{C}$ (Siewert et al 2014). In a previous study of Stewart (2008) the decisive temperature change took place in the timespan of approx. 4 min 30 IR-images were taken every 30 s before adrenaline infusion and 30 IR-images after infusion and compared with the control group which received an isotone saline solution. The maximum temperature values $(n=30)$ at the medial angle of the eye were averaged before and averaged after the adrenaline infusion. The observed maximum drift error within a time interval of one minute can be in the order of magnitude of 0.4 to $0.65^{\circ} \mathrm{C}$ (Siewert and Dänicke et al. 2014). This cited characterisation of thermal infrared cameras was carried out with two IR cameras, using an uncooled microbolometer array as detector. One of these IR-cameras was identical to the IRcamera type VariaCAM (production year 2009) used in the present study. In the present study the measurement error was minimised by a difference calculation using a difference ROlmethod (Siewert et al. 2010 and 2014).

In an experimental study assessing pain during chirurgical castration on calves $(n=16) 8$ of which were in the control group (Stewart et al. 2010b) a significant increase in the measured heart rate $(+15.1 / \mathrm{min}, \mathrm{p}<0.05)$, of the adrenaline $(+50 \%, p<0.05)$ or noradrenalin concentration $(+300 \%, p<0.001)$ in blood plasma after surgical castration was observed. A significant increase in heart rate caused by pain resulting from colic was reported in a study of Hinchcliff (2005) on 35 horses with a colic $(r=0.68, p<0.001)$.

The result of the intravenous infusion of adrenaline with calves (Stewart et al. 2010a) confirms the physiological effect, that after the moment of starting the adrenalin infusion the sympathetic nervous system causes a vasoconstriction of the blood vessels (skin, mucosa) analogous to the blood vessels of the brain (Thews and Mutschler 2007, p.657). This led to a decreasing perfusion and resulting decrease in surface temperature in the regions of the lacrimal sacks located at the medial angle of the eyes.

\section{Classification I: $\Delta \vartheta R O / s$ stable - minor changes}

$\triangle \vartheta R O \mid 4$ most stable: minor changes in the temperature difference

A time-dependent course with a stable characteristics especially the smallest relative percent range of variation with $8 \%$ (cf. Tab. 4) was present during the duration of the experiment on $\triangle$ YROI4 (cf. Tab. 4-7). This result was consistent with not significant $p$-values ( $p \geq 0.2$; Wilcoxon signed rank (multiple comparison) test) (cf. Tab. 5) during the duration of the training. The correlation test according to Spearman was not significant with the parameter of the heart rate $\left(p>0.60, r_{s}=-\right.$ $0.13)$ and respiratory rate $\left(p \geq 0.34, r_{s}=0.24\right)$. This test is consistent to a not significant result of the multiple regression analysis. The measuring area $\mathrm{ROI} 4$ includes the arteria/vena facialis in the area of the branch-off of the arteria/vena labialis inferior. The blood vessels are embedded in fatty tissue by and additionally covered by musculature and the head fascia (Nickel et al. 1996, Nickel et al. 2001, Popesko 2007)(cf. Fig. 3 and 5). The blood vessels are located deeper and covered by more tissue in comparison to the regions in classification III and ROII. 


\section{$\Delta \vartheta R O I 3$ very stable}

$\Delta$ ҮROI3 (cf. Tab. 4-7) has the same classification like $\triangle \vartheta R O \mid 4$. A very small relative percent range of variation with $8.8 \%$ (cf. Tab. 4). This result was consistent with not significant $p$-values ( $p \geq 0.3$; Wilcoxon signed rank (multiple comparison) test) (cf. Tab. 5), a not significant correlation test according to Spearman with the parameters heart rate $(p \geq 0.51)$ and respiratory rate $(p \geq 0.19)$ (cf. Tab. 6) and a not significant result of the multiple regression analysis $(p \geq 0.35)$ (cf. Tab. 7).

\section{Classification II: Final statement impossible neither stable nor instable}

\section{$\Delta \vartheta \mathrm{ROI5.2, \Delta \vartheta ROI5.1,} \Delta$ ७ROI1}

However, instability decreases with rising deepness of the major blood vessel (arteria/vena angularis occuli) from $\Delta$ ७ROI6, $\Delta \vartheta R O 15.3$, over $\Delta \vartheta \mathrm{ROI5.2, \Delta \vartheta ROI5.1}$ up to $\Delta \vartheta \mathrm{ROI} 4$ with the maximum of stability. This is confirmed by increasing $p$-values $(0.001 \rightarrow 0.43 \rightarrow 0.811)$ in the Wilcoxon signed rank (multiple comparison) test for $\Delta$ VROl6 $\rightarrow 4$ between MTP2 and MTP1 (Tab. 5) and by IR-images processed with the relief procedure (Siewert 2009, Fleischmann 2009 et al.). In the region of ROI 6 and ROI5 (white circle, Fig. 5a) the blood vessel can be easily recognised but in the region of $\mathrm{ROI} 4$ it cannot be observed (dark arrow, Fig. 5b) in the processed IR-image, because musculature beginning with musculus zygomaticus (Fig. 2, nr. 5) covers with increasing tissue thickness the major blood vessel. A temperature decrease at the location of the levator nasolabialis muscle (Fig. 2, nr. 2) crossing the arteria/vena labialis superior can be observed in Fig. $5 a$. The IR-image was taken at a low ambient temperature $\left(12.6^{\circ} \mathrm{C}\right)$.

\section{$\Delta \vartheta R O I 1$ neither stable nor instable}

$\Delta \vartheta R O I 1$ has a relative percent range of variation with $20.7 \%$ and the reduction in the temperature difference was significant between (MTP1-3) with Wilcoxon signed rank (multiple comparison) test but not between (MTP1-2) or (MTP1-4). Besides, any significant correlation (Tab. 6) or multiple regression analysis (Tab. 7) occurred with the parameters heart rate $(\Delta H R)$ or respiratory rate $(\Delta R R)$.

\section{Classification III: $\Delta \vartheta R O /$ s instable - strong or major changes}

\section{$\Delta \vartheta \mathrm{ROI6, \Delta \vartheta ROI5.3}$}

$\triangle \vartheta \mathrm{RO}$ I 6 has the largest relative percent range of variation with $36.1 \%$ (Tab. 4). The reduction in the temperature difference was significant $(p \leq 0.001)$ with Wilcoxon signed rank (multiple comparison) for $\triangle \vartheta \mathrm{ROI5.3}$ and $\triangle$ YROI6 between MTP3 and MTP1 (Tab. 5). $\triangle$ YROI6 is the only one temperature difference which has significant $p$-values $(p \leq 0.004)$ between MTP2 and MTP1 (Tab. 5) and also MTP4 and MTP1. A significant correlation according to Spearman occurred with the parameter heart rate $\left(p<0.002, r_{s}=-0.68\right)$, (Tab. 6). This test is consistent with a significant result of the multiple regression analysis (coefficient of determination): $R^{2}=0.60$; predictor variables: $\Delta H R, \Delta R R),($ Tab. 7). $\Delta \vartheta R O 16$ had a large coefficient of determination compared to the other temperature differences and a significant $p$-value $(p=0.001$; group range. $\triangle$ YROI1-6: $p$ was between $0.001-0.9$, median 0.6 ). The measuring area after the arteria dorsalis nasi has left the end artery of the arteria facialis is defined as arteria angularis occuli (ROI6), which is located directly under the skin. (Nickel et al. 1996 and 2001, Popesko 2007).

The multiple regression analysis of $\Delta \vartheta R O I 5.3$ is with $p=0.12$ not consistent with the significant correlation according to Spearman with the parameter respiratory rate $(p<0.035$, $\left.r_{s}=0.5\right)$ and the other tests (Tab.4-5). Statistical methods like linear regression assume linear relations in the structure of $f(x)=m x+b$ (Cohen et al. 2002, SAS manual 2008, Gaus and Muche 2013), for optimal explanatory power. However the second term in eq. 5 prevents a linear relationship. Thus, it is not surprising that heterogeneous statements concerning the statistical methods may occur, because especially the relation of the body surface temperature to the perfusion or heart rate is non-linear (cf. eq. 5).

\section{Conclusion}

The aching face of a horse is described with an increased activity of the facial musculature (Meyer 1999). Through the increased use of musculature an increase in the surface temperature of the respective regions in the IR-images could be expected. In order to distinguish this increase resulting from muscular activity from the effects of a changed circulatory situation it was necessary to identify the regions containing the mimic muscles and simultaneously experienced almost any change caused by an increase in the heart- and respiratory rate. This for an evaluation preferred region was the area of the arteria/vena facialis at the branch-off of the arteria/vena labialis inferior ( $\mathrm{RO} / 4)$.

Evaluation methods for unilateral temperature differences at the horse's head which do not consider circulatory parameters (heart rate or respiratory rate) may show strong deviations in the order of magnitude of 10-30\% regarding the resting values.

\section{Acknowledgements}

Our thanks go to the Deutsche Forschungsgemeinschaft (DFG) for financial support of this study (project SE 859/6-1), to Prof. Carsten Staszyk (University of Gießen) for anatomical advice including the possibility to study head preparations and to Mrs. Frances Sherwood-Brock for critically reviewing the English. For the assistance in performing the experiments, we would like to thank Mrs. Haferkamp (General Radiology and Medical Physics) and the grooms of the Clinic for Horses, in particular, Mr. Nimoth.

\section{References}

Bergmann L., Schaefer C. (1943) Lehrbuch der Experimentalphysik: Band 1: Mechanik, Akustik, Wärme. de Gryter, Berlin

Budras K. D., Röck S. (2009) Atlas der Anatomie des Pferdes, 6. Aufl., Schlütersche, Hannover, p. 36 
Bussières G., Jaques C., Lainay O., Beauchamp G., Leblond A., Cadore J. L., Desmaizières L. M., Cuvelliez S. G., Troncy E. (2008) Development of a composite orthopaedic pain scale in horses. Res. Vet. Sci. 85, 294-306

Clark J. A., Cena K. (1972) Die Anwendung von ThermovisionsTechniken bei Tieren. Dłsch. Tierärztl. Wschr. 79, 292-296

Cohen J., Cohen P., West S. G., Aiken L. S. (2002) Applied Multiple Regression / Correlation Analysis for the Behavioral Sciences, 2nd edition, Lawrence Erlbaum, ISBN 0805822232, p. 117

Cook N. J., Schaefer A. L., Warren L., Burwash L., Anderson M., Baron V. (2001) Adrenocortical and metabolic responses to ACTH injektion in horses: An assessment by salivary cortisol and infrared thermography on the eye. Can. J. of Anim. Sci. 81, 621

Diakides M., Bronzino J. D., Peterson D. R. (2012) Medical Infrared Imaging, CRC Press, Boca Raton

Engelhardt von W., Breves G. (2010) Physiologie der Haustiere, 3. Aufl., Enke Verlag, Stuttgart, 184-186, 467-489

Fleischmann T., Siewert C., Staszyk C., Schulze M., Stadler P., Seifert H. (2009) Thermal imaging as an aid to the diagnosis of pain in horses - First results, In: Dössel O.; Schlegel W. C. (Hrsg.): IFMBE Proceedings 25 (II) 11 th World Congress on Medical Physics and Biomedical Engineering. Berlin Heidelberg New York, 277-280

Ford R. G., Ford K. T. (1997) Thermography in the diagnosis of headache. Seminars in Neurology 17, 343-349

Gaus W., Muche R. (2014) Medizinische Statistik, 1. Aufl. Schattauer, Stuttgart, p. 182

Gonzalez F. J. (2007). Thermal simulation of breast tumors. Rev. Mex. Fis. 53, 323-326

Graf von Schweinitz D. (1999) Thermographic diagnostics in equine back pain. Vet. Clin. North Am. Equine Pract. 15, 162-177

Hassan M. Chernomordik V. et al. (2008) Infrared imaging for functional monitoring of disease processes. In: Diakides N. A., Bronzino J. D. Medical Infrared imaging, CRC Press, Boca Raton, 14-17

Hinchcliff K. W., Rush B. R., Farris J. W. (2005) Evaluation of plasma catecholamine and serum cortisol concentrations in horses with colic, J. Am. Vet. Med. Assoc. 227, 276-280

Infratec GmbH (2009) Benutzerhandbuch VarioCAM high resolution, Dresden, Germany

Krogbeumker B., Siewert C., Staszyk C., Bienert A., Ohnesorge B., Seifert H. (2009) The passive infrared thermography as addition to diagnostics of diseases in the head region of the horse - First results. In: Dössel O., Schlegel W. C. (Hrsg.): IFMBE Proceedings 25 (II) 11th World Congress on Medical Physics and Biomedical Engineering. Springer, Berlin Heidelberg New York, 221-224

Krogbeumker B., Siewert C., Bienert-Zeit A., Rohn K., Staszyk C., Ohnesorge B., Seifert H. (2014) The passive infrared thermography as addition to diagnostics of diseases in the head region of the horse, Abstract accepted by GEVA (German Equine Veterinary Association)-GPM International Congress Munich for Nov. 2014

Menzel A., Siewert C., Gasse H., Höltig D., Beyerbach M., Seifert H., Waldmann K. H., Hennig-Pauka I. (2014) Infrared Thermography of the Pig Thorax: An Assessment of Selected Regions of Interest by Computed Tomographical and Anatomical Parameters Anatomia, Histologia, Embryologia, http://onlinelibrary.wiley.com/doi/ 10.1111/ahe.12115/pdf

Meyer H. (1999) Zum Problem des Schmerzes und seiner Feststellung, Pferdeheilkunde 15, 193-220

Nickel R., Schummer A., Seiferle E. (1996) Anatomie der Haustiere Band III - Kreislaufsystem, Haut und Hautorgane, 3. überarbeitete Aufl., Parey Verlag, Berlin

Nickel R., Schummer A., Seiferle E. (2001) Anatomie der HaustiereBewegungsapparat Band I, 7. durchgesehene Aufl., Parey, Berlin, p. 319

Pennes H. H. (1948) Analysis of tissue and arterial blood temperatures in the resting human forearm. J. Appl. Physiol. 1, 93-122

Planck M. (1900) Zur Theorie des Gesetzes der Energieverteilung im Normalspectrum, In: Verhandl. Dtsch. Phys. Gesellschaft, December, Berlin

Popesko P. (2007) Atlas der topografischen Anatomie der Haustiere, 6. aktualisierte Aufl., Enke Verlag, Stuttgart

Purohit R. C., McCoy M. D., Bergfeld W. A. (1979) Thermographic diagnosis of Horner's syndrome in the horse. Am. J. Vet. Res. 41, $1180-1182$

SAS Institute Inc. (2008) 9.2 User's Guide, Introduction to Regression Procedures, Cary, NC, USA, 76-107
Savary P., Hauser R., Ossent P., Jungbluth T., Gygaxy L., Wechsler B. (2008) Eignung der Thermographie zur Erfassung von Entzündungen an den Gliedmaßen von Mastschweinen. Dtsch. Tierärztl. Wschr. 115, Nr. 9, 324-329

Saxena A. K., Willital G. H. (2007) Infrared thermography: Experience from a decade of pediatric imaging. Med Eng Technol., 1-12 Schulze M. (2004) Thermographie am Huf. Diss. Med. Vet. Hannover Siewert C., Brosig B., Döll S., Rohweder D., Dänicke S., Seifert H. (2010a) Differenzverfahren zur Analyse von Temperaturverteilungen im Infrarotbild am Beispiel von induziertem Fieber beim Schwein - Erste Ergebnisse. In: 41. Wissenschaftliche Tagung der Deutschen Gesellschaft für Medizinische Physik (DGMP 2010), (Hrsg.: N. Hodapp, J. Hennig, M. Mix). Freiburg, Tagungs-CD, pp. 510-512

Siewert C., Dänicke S., Döll S., Brosig B., Rohweder D., Beyerbach M., Seifert H. (2014) Difference method for analysing infrared images in pigs with elevated body temperatures. Zeitschrift für Medizinische Physik 24, 6-15

Siewert C., Hellige M., Heuchert N., Busley D., Schrock P., Rohn K., Stadler P., Seifert H. (2013) Beurteilung der Durchblutung am Pferdekopf im Infrarotbild unter Berücksichtigung von Umgebungstemperatur und Fell-Länge, 44. Jahrestagung der Deutschen Gesellschaft für Medizinische Physik e.V. (DGMP 2013), (Hrsg.: H. Trever) Köln, Tagungsband ISBN: 978-3-9816002-1-6

Siewert C., Staszyk C., Seifert H. (2010b) Einfaches FEM-Modell zur Berechnung der Temperaturverteilung am frontalen Pferdekopf Erste Ergebnisse. In: 41. Wissenschaftliche Tagung der Deutschen Gesellschaft für Medizinische Physik (DGMP), (Hrsg.: N. Hodapp, J. Hennig, M. Mix). Freiburg, Tagungs- CD; 610-612

Siewert C., Staszyk C., Bienert A., Krogbeumker B., Ohnesorge B., Seifert H. (2009) A new method of image processing for high-contrast medical infrared imaging of the horse. In: Dössel O.; Schlegel W.C. (Hrsg.): IFMBE Proceedings 25 (IV) 11 th World Congress on Medical Physics and Biomedical Engineering. Springer, Berlin Heidelberg New York, 556-559

Siewert C., Staszyk C., Bienert-Zeit A., Ohnesorge B., Seifert H. (2011) Einfluss der Parameter Umgebungstemperatur und Durchmesser der nasalen Luftwege auf die Temperaturverteilung am Pferdekopf, 3 Ländertagung der ÖGMP, DGMP, SGSMP in Wien http://www.medacad.org/medphys/ 2011 MedphysAbstracts.pdf

Stewart M., Webster J. R., Verkerk G. A., Schaefer A. L., Colyn J. J., Stafford K. J. (2007) Non-invasive measurment of stress in dairy cows using infrared thermography. Physiol. Behav. 92, 520-525

Stewart M. (2008) Non-invasive measurement of stress and pain in cattle using infrared thermography, PhD thesis Massey University, Palmerston North, New Zealand

Stewart M., Stafford K. J., Dowling S. K., Schaefer A. L., Webster J. R. (2008) Eye temperature and heart rate variability of calves disbudded with or without local anaesthetic. Physiol. Behav. 93, 789-797

Stewart M., Webster J. R., Stafford K. J., Schaefer A. L., Verkerk G. A. (2010a) Technical Note: Effects of an epinephrine infusion on eye temperature and heart rate variability in bull calves. J. Dairy Sci. 93, 5252-5257

Stewart M., Verkerk G. A., Stafford K. J., Schaefer A. L., Webster J. $R$. (2010b) Noninvasive assessment of autonomic activity for evalvation of pain in calves, using surgical castration as a model. J. Dairy. Sci. 93, 3602-3609

Thews G., Mutschler E., Vaupel P. (2007) Anatomie, Physiologie, Pathophysiologie des Menschen, 6. Aufl. WVG, Stuttgart, p. 657

Turner T. A., Purohit R. C., Fessler J. F. (1986) Thermography: A review in Equine Medicine. Comp. Equine 8, 855-861

Turner T. A. (1991) Thermography as an aid to the clinical lameness evaluation. Vet. Clin. North Am. Equine Pract. 7, 311 -338

Turner T. A. (2001) Diagnostic thermography. Vet. Clin. North Am. Equine Pract. 17, 95-113

Vollmer M., Möllmann K. P. (2010) Infrared Thermal Imaging. Weinheim: Wiley-Vch.

Zheng L., Wen-Jei Y. (1990), Whole body heat balance during the thoracic hyperthermia, Med. Biol. Eng. Comput. 28, 171-181

Zierz J. (1993) Die Quantifizierung akuter Schmerzen beim Pferd mittels physiologischer und ethologischer (klinischer und verhaltenstypischer) Parameter sowie deren Korrelation zur aktuellen Plasmakonzentration von Adrenalin und Noradrenalin. Ein Beitrag zur Schmerzmessung beim Pferd. Diss. Med. Vet. Berlin 